\title{
The geochronology of a palaeolake at the Pleistocene/Holocene transition in the Muya-Kuanda Basin (Eastern Siberia, Russia)
}

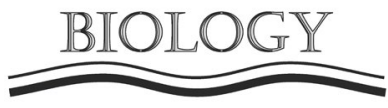

www.limnolfwbiol.com

\author{
Ineshin E.M. ${ }^{1 *}$, Ruposov V.L. ${ }^{2}$, Buyantuev V. ${ }^{3}$, Voronin V.I. ${ }^{3}$, Oskolkov V.A. ${ }^{3}$, \\ Moritz R.A. ${ }^{3}$, Hommel P. ${ }^{4}$
}

${ }^{1}$ Irkutsk State University, Irkutsk, Russia.

${ }^{2}$ Irkutsk National Research Technical University, Irkutsk, Russia.

${ }^{3}$ SIFIBER SB RAS, Irkutsk, Russia.

${ }^{4}$ University of Liverpool, Liverpool, $U K$

\begin{abstract}
This article presents new data on the study of preserved wood from flooded forests in the Muya-Kuanda Basin, Eastern Siberia. On the basis of the stratigraphic position of a buried tree stump horizon, the analysis of the associated alluvial deposits and a new programme of radiocarbon dating, the chronology of formation and collapse for a Late Pleistocene palaeolake in the Muya-Kuanda Basin can be precisely determined. The accuracy of dating of geological events with the radiocarbon method and the possibility of linking them to calendrical dates is discussed. As a result of this research it is possible to connect the geochronology of the lake with archaeological sites in the Vitim Basin, both upstream and downstream along the river. The reasons for the periodic formation of substantial bodies of water in the Muya-Kuanda Basin are also discussed, with implications for decision making with regard to the modern economic development of the region.
\end{abstract}

Keywords: Flooded forest horizon, dendrochronology, palaeoclimate, dammed lake, archaeological sites, fault valley, radiocarbon dating

\section{Introduction}

Stump horizons are, in terms of the accuracy of the dating of geological events, one of the most valuable sources available to geochronologists. They are formed during the catastrophic (single event) flooding of forest landscapes as vegetation, including trees are buried in situ by a significant depth of sediment accumulating at the bottom of a rapidly forming body of water. Three remarkable examples of such horizons have been found in the Muya-Kuanda Basin and, unlike almost all other sources, they provide direct evidence for the presence of a series of dammed lakes in the Muya-Kuanda Basin, as well as evidence for the duration of each phase of flooding. These stump horizons, named after the places where they were identified correspond to different chronological periods (given in uncalibrated radiocarbon years before present (bp)): Sukhokit stump horizon - $12124 \pm 25-11967 \pm 24$ bp (Sukhokit Stage), Shchuchya channel (27630 $\pm 385-27470 \pm$ 320 bp) (Shchukin stage), Kobylin channel (34880 \pm $260-41080 \pm 500 \mathrm{bp}$ ) (Kobylin stage of backwater body) (Table).

The Sukhokit stump horizon, which is the subject of this article, was discovered and first studied by A.A. Kulchitsky (Kulchitsky and Orlova, 1991; Kulchitsky et al., 1997). These researchers obtained the first radiocarbon dates (via the scintillation method) for buried wood, and proposed a tectonic cause for the damming of the Param canyon and the formation of a substantial backwater lake in the chronological range 12,300 - 10,300 bp (Kulchitsky et al., 1997). However, unlike other stump horizons in the basin, which have since been revisited by a range of other researchers, the stump horizon at the mouth of the Sukhokit stream has seen no further study.

This is perhaps because researchers investigating these horizons saw them only as a way of dating the formation of particular geological deposits and events. There has been no comprehensive investigation of the stratigraphy of sandy deposits, the characteristics of the forest vegetation, the process of burial, or the wood remains themselves. Moreover, there has been no attempt to extract palaeoclimatic information from this valuable source or to correlate it with the of the study of archaeological remains in the Muya-Kuandinsky depression, or more broadly across the Vitim Basin. This study aims to redress this imbalance and present 
results that begin to fill this gap in our knowledge.

\section{Materials and methods}

In order to obtain the maximum number of samples from the reference horizon - where the tree trunks were located in situ - we re-examined and further studied the exposure described by A.A. Kulchitsky at the mouth of the Sukhokit stream, a left-hand tributary of the Muya River (Kulchitsky et al., 1997) (Fig. 1B). This allowed us to clarify the stratigraphy of the section, to take samples for further dating of the geological events recorded in the loose deposits of the strata and obtain trunk material from which to contribute to the continuous tree-ring chronology of North Asia. An important aim of the study was to synchronise the formation of the stump horizon with other archaeological sites, both upstream and downstream along the Vitim which had been previously subjected to AMS dating. The total length of the section, exposed along the left bank of the Muya River at a height of 1518 meters above the modern river level, is 370 meters. In this section which both the remains of the stump horizon itself and sediments associated with the ancient mouth of the Sukhokit stream were recorded.

The latter sediments, associated with the ancient mouth of the Sukhokit stream, are located 230 meters downstream from the modern mouth and 15 meters higher than its current level. and is filled with buried wood. The depth of burial of the stump horizon from the modern surface varies between 3 - 4 metres along the strike of the section and occupies a sub-horizontal position along the strike. The stump horizon itself is a buried soil of a floodplain type (black dense humus sandy loam with forest litter of twigs, leaves, moss, fallen trees), with remains of well-preserved erect tree trunks in situ (Fig. 2; Fig. 3). It varies in thickness between $3-7 \mathrm{~cm}$ along the strike and is washed out in places. The soil is overlain by dense gleyed heavy loam of gray-bluish color, interbedded with interlayers of light yellow alluvial sand. In total, 23 specimens of well-preserved trunks in situ were taken directly from the stump horizon, and 4 specimens of buried wood were taken from the ancient channel of the Sukhokit stream, which is epigenetic to the stump horizon.

\section{Results and discussion}

\subsection{The structure of the sedimentary deposits and evidence of the palaeolake}

The stumps of trees with a root system and a height of $0.4-0.7$ meters observed in the section (the height of the stumps corresponds to the thickness of the overlying sands with subhorizontal or oblique bedding) are at a distance of 1 to 4 meters from each other, which corresponds almost precisely to the density of the stand of larch and spruce on the modern floodplain the Muya River. Among the recorded trunks of the stump horizon, all specimens belong to larch (Larix sibirica) (Fig. 3A, 3B). The wood of the preserved dark gray larch trunks is dense and well preserved. The diameter of the trunks ranges from 7 to $13 \mathrm{~cm}$ (Fig. 3A, 3B). The time span of the trees of the Sukhokit stump horizon covers an approximately 200-year period. The height of the stumps corresponds to the thickness of the lacustrine sands overlying the buried soil.

The well-preserved trees and forest litter between

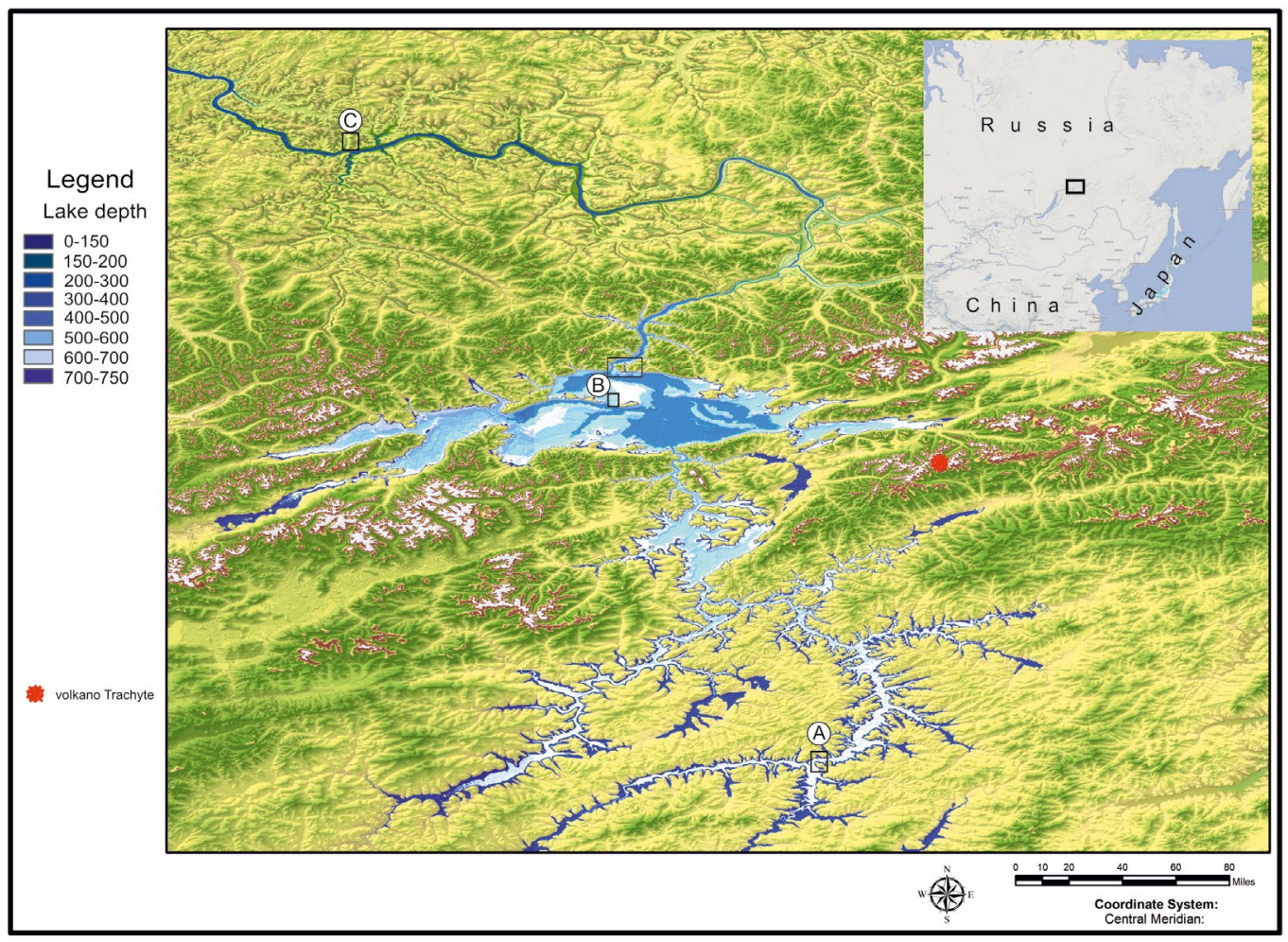

Fig.1. Map of the model of the palaeolake of the Sukhokit stage (11967 - 12124 bp). A - Ust'-Karenga archaeological complex, B - section of the stump Sukhokit horizon, C - section of the multilayer archaeological site Bolshoy Yakor I. 
Ust'-Karenga

A

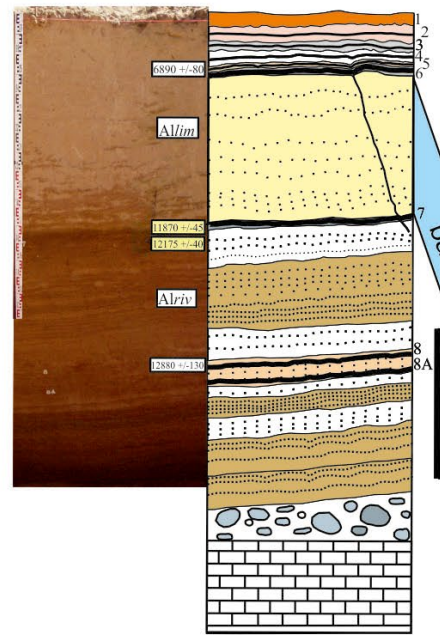

Sukhokit

B

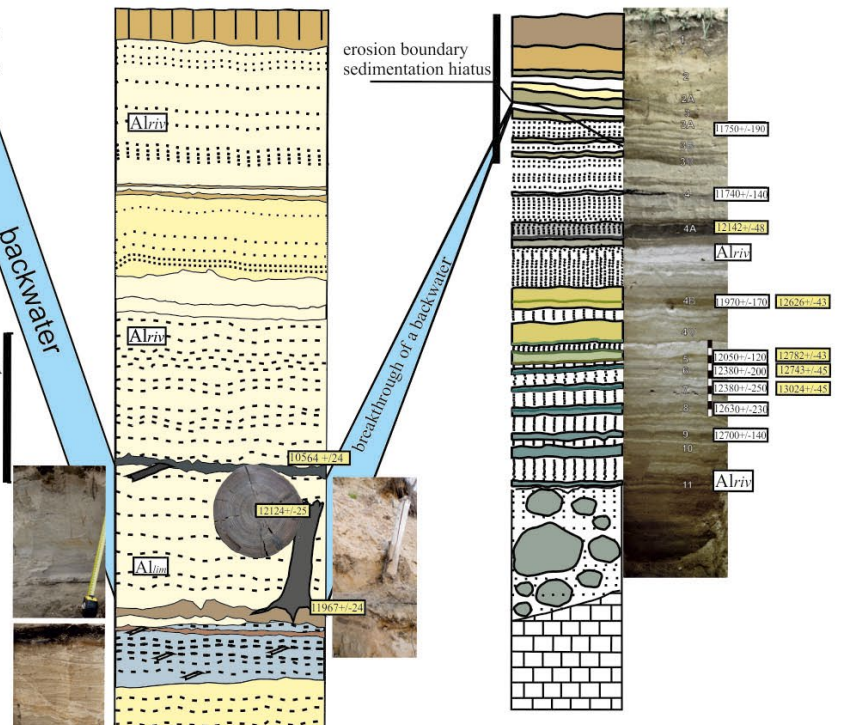

Fig.2. Scheme of reference sections: A - Ust'-Karenga archaeological complex, B - section of the stump Sukhokit horizon, C - section of the multilayer archaeological site Bolshoy Yakor I. 

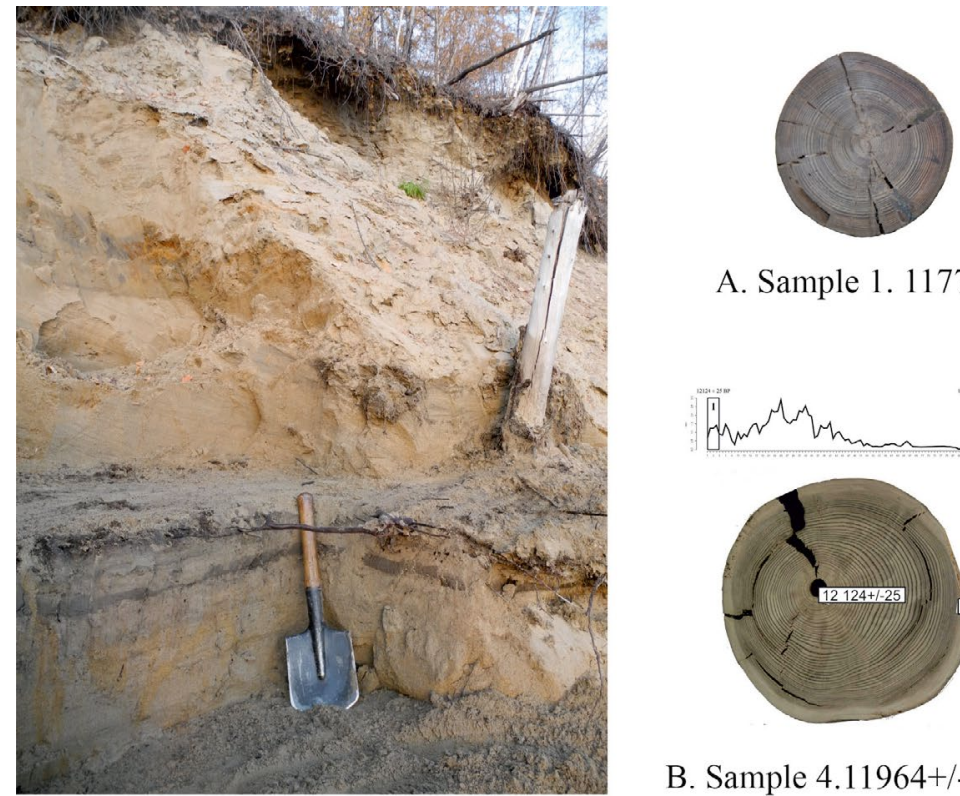

A. Sample 1. $11770+/-40$

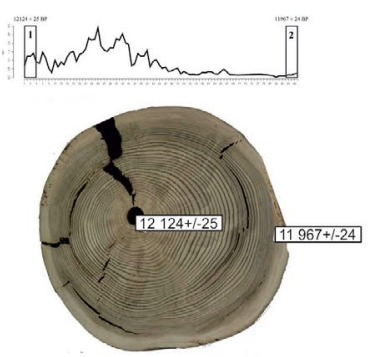

B. Sample 4.11964+/-24, $12124+/-25$

Fig.3. Cleaning of the stump horizon Sukhokit and sections of buried wood. A - Sample 1, B - Sample 4.

the trunks suggests a rapid rise in water levels and the flooding of the forest without a planar flow, which would have washed out detrital material. The rapid burial of tree trunks, their burial within dense finely dispersed sediments contributed to the isolation of the material from access to oxygen, and later, after the collapse of the palaeolake lake, the appearance of the permafrost effect contributed to the good preservation of wood and other organic matter (Fig. 3).

The following description details the stratigraphy from the section (from top to bottom) supplemented by illustrations (Fig. 2; Fig. 3).

Layer 1 - root bound soil with an abundance of organic matter up to $0.15-0.20 \mathrm{~m}$ thick. Layer 2 dense silty loam layers with unclear bedding - though some charcoal bearing layers in lower part of the deposit emphasize the stratification. At the bottom, the layers are also are deformed by cryogenic processes. The thickness of the strata along the strike of the section is consistent between 1.0 to $1.30 \mathrm{~m}$. Layer 3 - yellowgray polymict sands with interlayers of iron oxides. The sediments are alluvial in origin with varying depositional regimes from channel to floodplain facies of the river. The bedding of the strata along the strike of the section is parallel, changing to cross-bedded and channel-fill/ripple sediments. Frost wedges initiated in the upper part of the bed reach down to a depth of at least 3.5 meters. The thickness of the deposits ranges from 1.60 to $1.30 \mathrm{~m}$. Layer 4 - peaty palaeosoil (soil 2). A dense, compressed black histosol soil with poorly decomposed plant remains marking an extended period of waterlogging of the valley bottom associated with the collapse of the palaeolake lake and drainage of the bottom of the basin. The soil is saturated with the remains of woody vegetation in the form of roots, twigs, fragments of thin stems. This layer is clearly visible across the section with a variation in the thickness from 0.05 to $0.10 \mathrm{~m}$. AMS-dating obtained from the remains of woody vegetation in the soil provided a date of $10564 \pm 24$ (SUERC-87225). This dating allows us to establish a terminus ante quem date for the flooding of the basin. Layer 5 - Column greenish gray silty sands finely interbedded with silts; gleyed in the upper and lower parts with thin parallel bedding. In the middle part of the stratum, areas of dischordant bedding are noted. Lacustrine alluvium associated with the palaeolake lake. The thickness along the section is consistent, ranging from 1.05 to $1.0 \mathrm{~m}$. Trunks of buried trees extend through the stratum. The root systems of these trees continue into the palaeosoil (soil 1) which underlies the deposit. The upper parts of the tree, which would have extending beyond the upper boundary of the layer, have been broken off when the wood was still relatively fresh. Other than this, the trunks of the trees are perfectly preserved: they have bark and small twigs, and on the surface of the buried soil 1, the remains of forest litter - branches of trees, shrubs, and fallen cones is preserved. Further up in the stratum, there are occasional remnants of redeposited woody vegetation in the form of fragments of branches and tree roots. Layer 6 - dense peaty palaeosoil (soil 1). Along the strike of the section, this level is traced everywhere, although in some areas the soil is partially eroded. In a number of areas along the strike of the section, the soil is subdivided into separate humic interlayers containing organic remains alternating with gleyed bluish-gray interlayers of loam and light interlayers of fine-grained sand. Trees, almost exclusively larch (Larix sibirica), grew on this soil surface. The distance between trees is 1.0 to $4.0 \mathrm{~m}$, the thickness of the trunks is from 0.05 to $0.25 \mathrm{~m}$, the age is from 10 to 250 years. The height of the tree trunks ranges from 0.40 to $0.69 \mathrm{~m}$ and corresponds to the thickness of the bottom lake sediments that buried forest vegetation, which may indicate that the burial was quick and catastrophic. Soil 1 marks the level of the drained waterlogged terrace of the Muya River, which had emerged from the cycle of floodplain accumulation of alluvium and was actively overgrown with forest vegetation. Radiocarbon (AMS) dates for this layer were obtained from the last 5 annual rings of the oldest buried trunk recovered from the section - $11967 \pm 24$ (SUERC-87226) - and from 
Table. Information on wood samples

\begin{tabular}{|c|c|c|c|c|}
\hline Sample location & Lab number & Material & $\begin{array}{c}\text { Radiocarbon date }{ }^{14} \mathrm{C} \\
\text { (uncalibrated/bp) }\end{array}$ & Source \\
\hline Sukhokit, stump horizon, soil 2 & SUERC-87226 & $\begin{array}{l}\text { Wood of the first } 3 \text { an- } \\
\text { nual rings, sample } 4\end{array}$ & $12124 \pm 25$ & Own data \\
\hline Sukhokit, stump horizon, soil 2 & SUERC-87227 & $\begin{array}{c}\text { Wood of the last } 5 \text { an- } \\
\text { nual rings, sample } 4\end{array}$ & $11967 \pm 24$ & Own data \\
\hline Sukhokit, soil 1 & SUERC-87225 & Wood from soil 1 & $10564 \pm 24$ & Own data \\
\hline $\begin{array}{l}\text { Volcano Trakhitovy Udokan } \\
\text { volcanic field, soil from under } \\
\text { the lava flow }\end{array}$ & ГИН-4086 & Charred soil & $12050 \pm 650$ & Stupak, 1987 \\
\hline Dry stump horizon, soil 2 & BETA- 432243 & $\begin{array}{l}\text { Wood of annual rings, } \\
\text { sample } 1\end{array}$ & $11770 \pm 40$ & Own data \\
\hline $\begin{array}{l}\text { Muya river Kobylin channel, } \\
\text { soil } 1\end{array}$ & BETA- 453117 & $\begin{array}{l}\text { Wood of annual rings, } \\
\text { sample } 1\end{array}$ & $34880 \pm 260$ & Own data \\
\hline $\begin{array}{l}\text { Muya river Kobylin channel, } \\
\text { soil } 1\end{array}$ & BETA-453118 & $\begin{array}{l}\text { Wood of the last } 5 \text { an- } \\
\text { nual rings, sample } 1\end{array}$ & $41080 \pm 500$ & Own data \\
\hline Muya river Shchuchya channel & COAH-3447 & $\begin{array}{l}\text { Wood from the stump } \\
\text { horizon }\end{array}$ & $27025 \pm 320$ л.н & $\begin{array}{c}\text { Filippov A.A., } \\
1997\end{array}$ \\
\hline $\begin{array}{c}\text { Ust'-Karenga-XII, excavation site } \\
\text { 3, united cultural horizon } 7\end{array}$ & TKA-19745 & $\begin{array}{l}\text { Organics from within } \\
\text { ceramic fabric }-7 \text { th } \\
\text { cultural horizon }\end{array}$ & $11825 \pm 45$ & Own data \\
\hline $\begin{array}{l}\text { Ust'-Karenga-XII, excavation site } \\
\text { 3, united cultural horizon } 7\end{array}$ & TKA-19743 & $\begin{array}{l}\text { Organics from within } \\
\text { ceramic fabric }-7 \text { th } \\
\text { cultural horizon }\end{array}$ & $12175 \pm 40$ & Own data \\
\hline $\begin{array}{c}\text { Ust'-Karenga-XIV, excavation } \\
\text { site } 12 \text {, united cultural horizon } \\
7 \\
\end{array}$ & TKA-19744 & $\begin{array}{l}\text { Organics from within } \\
\text { ceramic fabric }-7 \text { th } \\
\text { cultural horizon }\end{array}$ & $11870 \pm 40$ & Own data \\
\hline
\end{tabular}

the first annual rings of the same trunk - $12124 \pm 25$ (SUERC-87227) (Fig. 4). The preservation of the wood suggests that the sediments were frozen prior to the dissection of the left side of the channel by the Muya River. The position in the section is 13 meters above the current edge of the Muya River. Layer 7 a packet of parallel, thinly bedded loams and sands; gleyed, dark gray, with a bluish tint and fragments of plant remains in the form of twigs, stem fragments, debris. Sections with oblique bedding are recorded in the strata. Deposits of this type and dynamics of lamination are found at archaeological sites downstream along the Vitim, e.g. Bol'shoy Yakor I, Kovrizhka II and III. The thickness of the layer along the strike is variable from 1-2 m. Layer 8 - rhythmically layered sands and loams with interlayers of pebbles. The sands are well washed and sorted, and the pebble interlayers are themselves interlayered with silt. Fragments of a bison skull (Bison $s p$.), and the teeth of a horse (Equus caballus) were found in a redeposited state at the base of the sediments near the water's edge. The thickness of the deposit is c. $10 \mathrm{~m}$. Layer 9 - has a pebble-boulder base, a stone substrate of varying degrees of roundness and sizes from $1 \times 0.7 \mathrm{~m}$ to $0.20 \times 0.10 \mathrm{~m}$. The stone substrate includes granites, limestones, igneous rocks, aggregates, infilled with coarse and medium-grained sands. The observed thickness of the low-water level in the Muya River is about $1 \mathrm{~m}$ along the strike of the section.

On the basis of the structure, it can be assumed that in the middle part of the section (along the strike) corresponds with an ancient channel of the Sukhokit stream, the ancient mouth of the stream. The channel is filled with large quantities of wood residues, both in the form of whole trunks and their fragments in a good state of preservation. The tree species include spruce, pine, larch, birch, and poplar. The fill is represented by sands and loams in a layered form. The total depth of the channel cut is 6 meters and its width along the strike of the section is more than $10 \mathrm{~m}$. The channel cuts through the stump horizon and can be regarded as epigenetic in relation to the level of formation of the drained surface and its re-colonization by woody vegetation.

\subsection{Dendochronological reconstructions from buried trees}

For dendrochronological analysis, we took wood samples from the section of the Sukhokit stream and, for comparative analysis, from the much older section of the Kobylin channel. All samples were cross-dated, and 2 samples from Sukhokit. and one sample of the Kobylin channel were radiocarbon dated, which made it possible to obtain a relative time reference for these chronologies. In ten samples out of 23 obtained at Sukhokit, the date of death is the same, and dates back to -11950 . The date of death of 4 samples is in the range between -11950 and -11945 years, however, they may lose the last rings due to poor preservation. Crossdating of tree-ring series of samples of the Kobylin channel also showed a coincident date of death for four fossil tree samples. The consistent death of a large proportion of the trees found, given that the samples were collected in situ, confirms the catastrophic nature of the events (Fig. 4). 


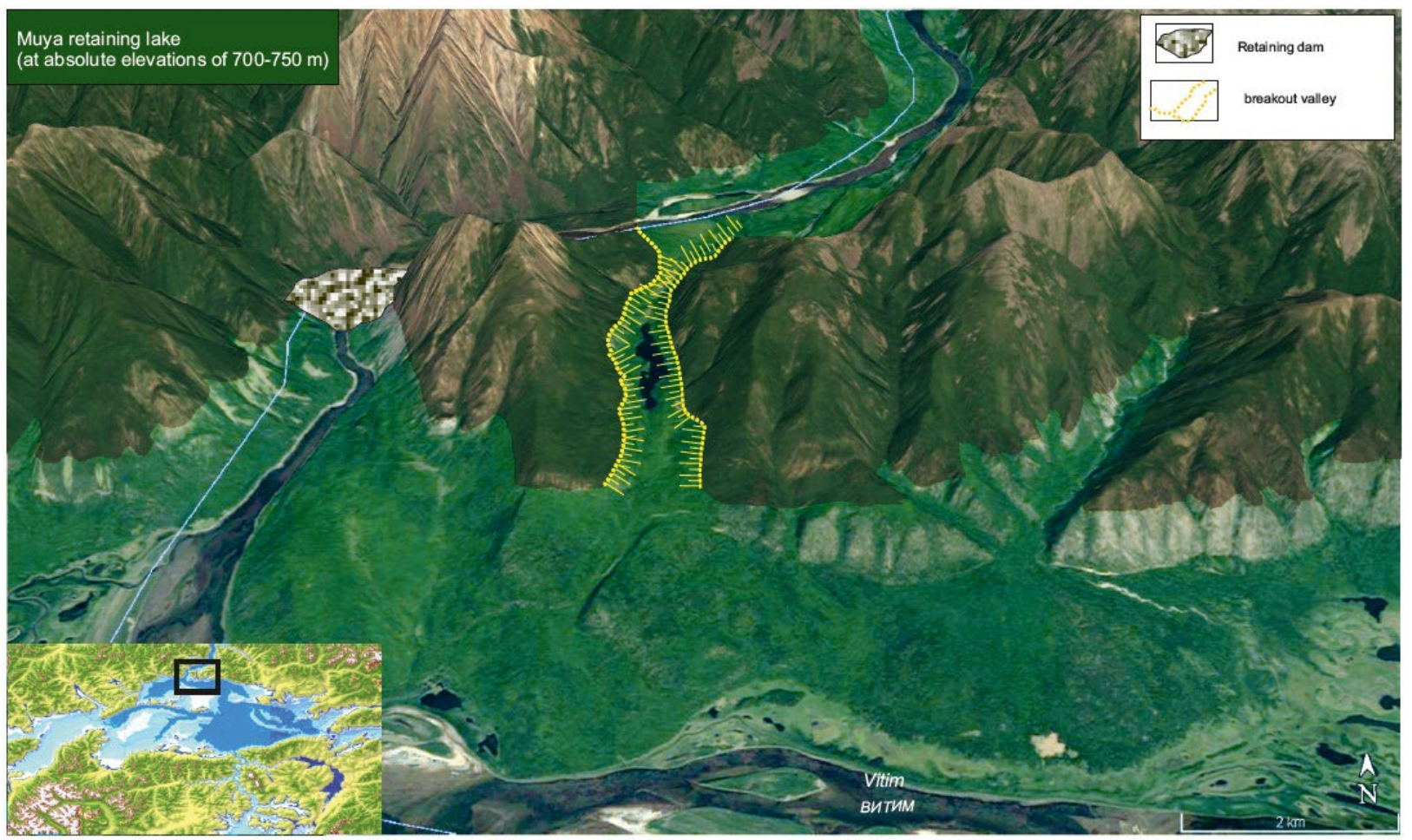

Fig.4. The level of the palaeolake of the Sukhokit stage (elevation $740 \mathrm{~m}$ above sea level) at the Param canyon and the Kilikanda valley spillway.

Tree-ring growth patterns, established on the basis of modern trees, show a reliable response to atmospheric moisture conditions and this enables a regional drought index to be established (Cook et al., 2010). In the growth ring dynamics of both the Sukhokit and Kobylin samples, several periods of depression are evident and typical for most samples (Fig. 5.) The average sensitivity index of the tree-ring series from Sukhokit is 0.31 , which indicates the presence of a pronounced response to environmental conditions in the studied tree-ring series. It can be assumed that the periods of depression in the chronologies "Sukhokit" and "Kobylin channel" are closely related to droughts. However, while the average tree-ring width in the Sukhokit samples correlates with the tree-ring width of modern trees, the average tree-ring width in the Kobylin channel samples is significantly lower. The sensitivity index of the Kobylin samples is somewhat higher, calculated as 0.35 , and the periods of depression are more pronounced.There is reason to believe that during the life of the trees found in the Kobylin channel, the environmental conditions differed significantly both from those during the life of the Sukhokit trees and from modern conditions (Table). Probably, the varation in radial growth in the samples of the Kobylin channel reflect a response to temperatures rather than precipitation, and chronological depressions are associated with periods of intense cold.

It is important to note that periods of growth supression have a periodicity.The tree-ring chronology "Sukhokit" contains a fairly stable 11-year cycle, corresponding to the cyclical nature of solar activity. The frequency of manifestations of periods of depression increases around the time of death of the trees and the catastrophic flooding of the basin.

\subsection{Palaeoreconstruction of the dammed lake formation}

In the Sukhokit section, a chain of successive geological events is recorded, which affected the vast territory of the Vitim plateau and the Baikal-Patom plateau. The first event (from bottom to top along the section) is the emergence of the terrace-like surface in the bottom of the Muya-Kuanda depression from the dynamic regime of formation due to periodic flooding. It is fixed by the 1st buried soil and tree trunks of various ages (from 89 to 48 years), which all died at the same time. The second event is the catastrophic flooding which not only filled the Muya-Kuanda basin, but also the valleys of the Vitim and its tributaries up to $500 \mathrm{~km}$ upstream. This is recorded by a layer of lacustrine alluvium that overlapped the larch forest that grew during the "dry period" of soil formation (the stump horizon itself). The depth of this lake was $110 \mathrm{~m}$, and resulted in the deposition of a significant volume of lacustrine sediments not only at the site itself but across the ancient landscape, including those where ancient human settlements have since been found - e.g. at the mouths of the Karenga, Yumurchen, Oktorokon rivers. (Fig. 2). According to radiocarbon dating, the existence of this vast lake is between $11967 \pm 24$ (the date of death of the trees) and $10564 \pm 24$ (the time of the formation of the 2nd buried soil), that is, 1175 years. The third event is the catastrophic collapse of the lake, traces of which are recorded downstream along the Vitim in the form of extreme levels of erosion in the sections of the sides of the valley, the deposition of giant boulders on various forms of relief, the deposition of sandy strata both in the Vitim valley and in the valley of the river Lena (Peleduysky and Nyuysky sites). The 


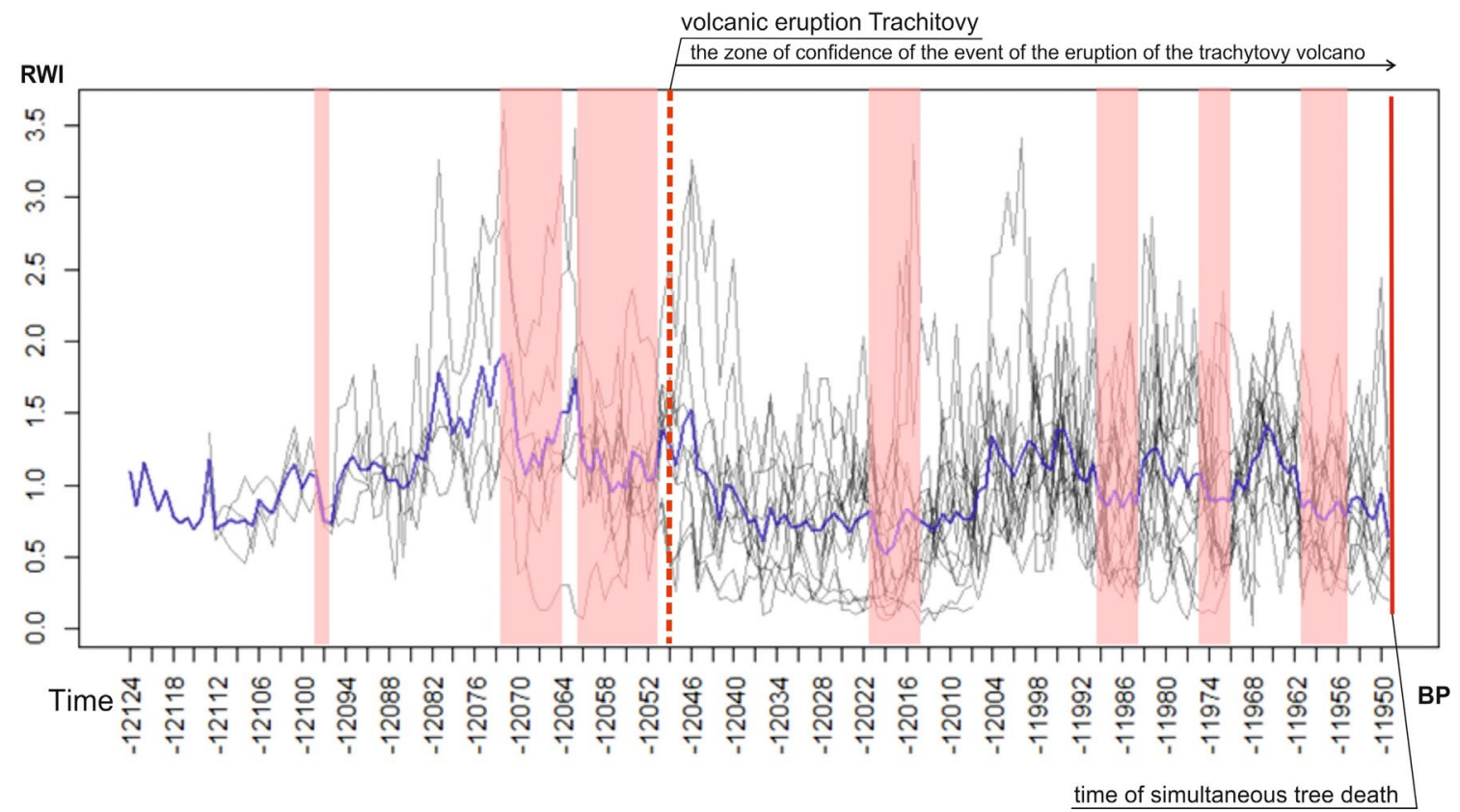

Fig.5. Individual tree-ring series (the average value is shown in blue, the characteristic periods of depression are highlighted in red).

fourth event is the drainage of the bottom of the MuyaKuanda basin, which is recorded by the formation of the 2nd buried soil. The period of drainage of the bottom of the basin, judging by the thickness of the soil, was shorter than the period of formation of the 1st soil. After the formation of the 2nd buried soil, the humidity in the region suddenly increases again and this surface for the second time passes into the regime of rhythmic river alluvial accumulation with the deposition of sands and loams, which sealed the earlier deposits.

The section at the mouth of the Sukhokit is, perhaps, the only one in the Muya-Kuanda basin, where the time of the existence of this palaeolake can be dated so accurately and reliably. Based on this, the question arises: what reasons can explain such sudden, sometimes catastrophic, transformations of the Vitim and Baikal-Patom plateaus? What are the timelines for these geological events?

Floodplain stabilization, associated with the end of regular alluvial accumulation on the terrace of the Sukhokit stream before the formation of the palaeolake was accompanied by waterlogging and the formation of peaty soils (soil 1). The subsequent overgrowing of the bottom of the basin with forest was associated with a period of low water levels in the region's rivers, when the amplitude of annual floods was insignificant and the terrace-like surface at the mouth of the Sukhokit stream was not flooded. This is confirmed by the analysis of the structure of annual rings in the tree trunks of the stump horizon, which indicate their formation in a relatively dry cold season (Fig. 3A, 3B; Fig. 5). What time period this process took is not yet clear, but as a first approximation, we can estimate at least 200 years, which were required for the growth of the trees themselves, plus the preceding time for the formation of the peaty soil itself. After the collapse of the palaeolake, the terrace-like surface at the mouth of the Sukhokit was again drained and passed into a cycle of soil formation, which is later replaced by a second phase active floodplain accumulation (Fig. 2).

The first soil (soil 1), on which forest vegetation settled belongs to the type of floodplain soils in which the process of soil formation itself was incomplete. The soil itself consists of several thin humus interlayers of loam and peat, separated by thin layers of light sand. Soil of this type can be observed on today's low floodplain of the Muya River, which is also covered with forests (spruce, larch, birch, pine), but periodically warms up during summer floods, leaving on forest litter and grass growing on the low floodplain an interlayer of fine-grained sand and silt (Fig. 3). In the composition of thin humus interlayers, there is an abundance of branches of woody vegetation, seeds, and fragments of wood. As noted above, this circumstance indicates that the formation of the soil itself, on which the forest of the Sukhokit stump horizon grew, took place under conditions reminiscent of the formation of the low floodplain of the Muya River today, subject to periodic flooding. However, this period was not long-term and took no more than $100-200$ years.

As noted above, three radiocarbon dates were obtained from the stump horizon using wood. The first AMS-date (sample No. 1-2017) from a tree trunk that lived for 68 years $11780 \pm 40$ (BETA-432243) bp. was obtained in the Miami laboratory (USA). For a more accurate adjustment of the AMS dating method itself and to create a chronological reference point for local tree-ring chronology (with reference to an absolute time scale), two more AMS were obtained from the trunk of a tree (No. 4-2018) that, judging by the annual rings, lived for 89 years. As noted above, this sample was dated in the laboratory of the University of Glasgow (UK) (Fig. 4), providing dates for the beginning of tree growth $-12124 \pm 25$ (SUERC-87227) bp - the end of growth, caused by simultaneous mass death of trees in the flooded forest $-11967 \pm 24$ (SUERC-87226) bp (Fig.5). This operation served as a pleasing confirmation of the accuracy of the AMS dating technique. Taking 
into account the corrections to the dating, the age of the tree at the end and start dates is 107 years, which is an almost ideal definition of the real age, calculated by the annual rings, equal to 89 years! It should be noted that in the future there is the possibility to link this floating section of tree chronology to a continuous regional tree-ring chronology, and thereby achieve calendar accuracy of geological events. In the process, it is necessary to clarify that when comparing radiocarbon dates from different sections of the Vitim, we used only the results obtained by the AMS dating method. This refinement is essential, especially for determining the course of geological events of short duration, since from our own research we established and documented a significant difference between radiocarbon dating obtained by scintillation and AMS methods. In our case, this difference is calculated in $660-740$ years. Evidently, this is of fundamental importance.

In ten samples of buried trees out of 23 excavated from the Sukhokit horizon, the date of death of trees coincides, and is determined by the boundary of 11967 $\pm 24 \mathrm{bp}$. Noteworthy is the fact that the dating of the palaeomagnetic excursions "Gothenburg" (12350 - 12400) and "Lashamp-Kargopolovo" (41000 bp) coincide with the dating of the palaeolakes of both the Sukhokit and Kobylin stages (Mörner, 1977; Krivonogov, 2001; Guskova et al., 2012; Nowaczyk et al., 2012). It is possible that the reason for the lower water levels in the Muya and Vitim, which resulted in a sudden end to the rhythmic process of the alluvial accumulation on the floodplain should be sought in these geomagnetic phenomena; in this case, "Gothenburg", which judging by radiocarbon dating - immediately preceded the growth of forest vegetation on the floodplain. It is also possible that the evolution of the position of the Earth's core and associated geomagnetic changes caused increased volcanic activity in the region. This may be confirmed by dating of a soil $(12050 \pm 650$ [GIN-4086]) which formed before the Trakhitovy eruption and was buried beneath the lava flow of the volcano on the Udokan volcanic plateau (Fig. 1) (Stupak, 1987). Some discrepancy between this dating and the date of the death of trees as a result of flooding on Sukhokit should be expected here, due to differences in the dating methodology and the specific character of the dated organic matter in each case. The date of the volcanic eruption was measured by the scintillation method, while the others used in the article use the AMS method. These methods vary considerably in the precision of measurement.

It is also worth noting, in this context, that Trakhitovy Volcano is located in close proximity, just $40 \mathrm{~km}$, from the Param canyon section of the Vitim valley, where a water-retaining dam could have formed (Fig. 1; Fig. 4) (Stupak and Stupak, 1987; Kulchitsky et al., 1997). The formation of the dams for these palaeolake lakes is explained by different researchers in different ways: some adhere to the view that tectonic movements were involved, leading to the collapse of the Vitim valley in the Param canyon and the blocking of the channel (Kulchitsky A.A., Ufimtsev, Skovitina), many others see glacial action as the explanation for the formation of a retaining dam, a glacier presumably descending along the valley of what is now Lake Oron (Endrikhinsky et al., 1983; Filippov, 1997; Enikeev, 2009; Margold et al., 2018). In this context

In determining the position of the shoreline and, therefore, the maximum extent and volume of the palaeolake, the section of the Vitim valley at the outflow of the Muya-Kuanda basin is of central importance. This was noted from the first by researchers of Lake Muya, S.S. Osadchiy and A.A. Kulchitsky, who described a "breakthrough valley" in this area, which served as the outflow for part of the contents of the ancient lake, bypassing the retaining dam within the Vitim channel itself (Endrikhinsky et al., 1983; Kulchitskiy et al., 1997).

On the right side of the Vitim valley, at an absolute elevation of $740 \mathrm{~m}$, is preserved a section of side valley (spillway) through which the waters from the dammed lake were carried (Fig. 1; Fig. 4). The total length of this valley is $4,900-5,000$ meters with a maximum width of 750 meters and a depth of 180 meters. Lake Kilikanda, which now occupies the thalweg of a fragment of this ancient channel, and from which the valley gets its modern name. This lake reaches a depth of more than $12 \mathrm{~m}$ and contains practically no loose sediments of riverine origin: silts, sands, pebbles. In the bottom sediments of the lake, from a depth of about 8 meters, a 50-cm core was taken using an UWITEC unit. In general, the undisturbed sediments presented in this core, in thickness and material composition correspond to the Holocene sediments of similar lakes of the Baikal rift zone.

In its current condition, the Kilikanda discharge valley is an area with steep rocky sides and a bottom lined with remains of past rockslides. In the middle part of the valley on the right side, at an elevation of 860 meters, there is a fragment of pebbles from an older stage, when the valley had again served as a spillway. In the profile of the valley, on the right side, yet another rudiment is recorded, fixing earlier stage in the development of the valley, the shoulders of which are 37 meters above the bottom of the main valley (Fig. 1; Fig. 4). In this rudiment of an older valley, a small swamp-lake has also been preserved, though it has now passed into the stage of overgrowth.

In the opinion of the first researchers of palaeolakes in this region, all these indications show that the bed of the Kilikanda valley formed under the influence of repeated phases of extreme erosion resulting from the release of water from these dammed lakes, gradually deepening the valley, the last stage of which occurred with the formation of the dammed lake that flooded the forests of the Muya basin around 11967 bp (Endrikhinsky et al., 1983). Downstream, immediately behind Lake Kilikanda, the arched ridges of "giant ripples", formed by flows of discharged waters are clearly visible along the left side of the valley. These formations are composed of pebble-boulder deposits with sand-grit filler reaching a width of up to 40 meters at the base. The difference in height caused by this last stage of erosion is $263 \mathrm{~m}$ along the $4500 \mathrm{~m}$ of the valley (Fig. 4). 
In general, the dimensions of the Kilikanda valley correspond to the parameters of the modern Vitim channel in the Param canyon. The total length of the bypassed section of the Vitim valley, and hence the section occupied by the dam, is $11.4 \mathrm{~km}$ (Fig. 4). Judging by its position, could have arisen only under the conditions of the formation of a backwater in the Param canyon at the point where the Vitim leaves the Muya-Kuanda basin (Fig. 4). On this section of terrain there are no glacial landforms to point to a glacial origin of the retaining dam. The boundaries of the final forms of mountain-valley glaciers in the Baikal Upland were fixed by us at higher elevations located tens of kilometers from the Vitim valley (Ineshin, 2003). As noted above, several authors (Ufimtsev et al., 1997) have noted a probable tectonic origin for the retaining dam. Their arguments are based on the morphology of the slopes of the Vitim valley in this section of its valley and they propose a staged model of subsidence to explain the process. The remnants of these subsidence stages are traced along the left side of the Vitim valley in the Param canyon (Fig. 4). Unfortunately, the presence of a spill way in the Param Canyon was not considered by the researchers who put a glacial explanation for the origin of the palaeolake lake in the Muya-Kuanda Basin. Instead, they described a spill way downstream of the mouth of Lake Oron that redistributed part of the Vitim discharge bypassing the retaining dam in the Delunoron narrowing $116 \mathrm{~km}$ downstream of the Param narrowing (Margold et al., 2018).

\subsection{The connection between the palaeolake and archaeological sites}

Whatever its cause, the dammed lake occupied a vast territory, including not only the Muya-Kuanda basin, but also the Vitim valley and its tributaries upstream (Fig. 2). Understanding fully the impact of these catastrophic events on the human populations of the basin is still in its early stages, but it seems to be very direct. Lacustrine-type alluvial deposits are well documented at the multi-layered archaeological complex at the mouth of the Karenga River, the right largest tributary of the Vitim. One of the most extensively studied archaeological complexes in the region, the Ust'-Karenga complex is located $400 \mathrm{~km}$ upstream from the Muya-Kuanda Basin (Fig. 6) and consists of 15 multilayer sites, which were defined and excavated over a period of more than twenty years, beginning in 1975. The cultural remains of the lower horizons $(7,8,8 \mathrm{~A})$ were deposited under the conditions of the formation of river alluvium but were overlain by an almost $1.4 \mathrm{~m}$ thick layer of thinly bedded sterile sands with slightly different bedding dynamics to those below (Fig. 2A). Until recently, it was believed that the origin of this part of the deposit was also riverine. However, as the cultural remains are reliably dated by the radiocarbon method based on both charcoal from hearth deposits and organic matter in the fabric of ceramic vessels - it is possible to precisely compare and correlate the chronological position of the cultural remains and the dating of the remains from the Sukhokit section. The coincidence is striking: the dating of the 7th cultural horizon, which contains the oldest record of ceramic vessel production to the west of the Pacific watershed, immediately precedes both the accumulation of the thinly bedded sands and the formation of the palaeolake attested in the Sukhokit section (Table; Fig. 2A). It is true that the situation is complicated and the AMS dating of the cultural remains using organic matter from the ceramic fabric obtained by the AMS method at the archaeological complex itself indicates a certain variation in date between individual local points within the complex itself and the presence of cultural remains of different dates at the same point (Vetrov and Ineshin, 2019). However, in general

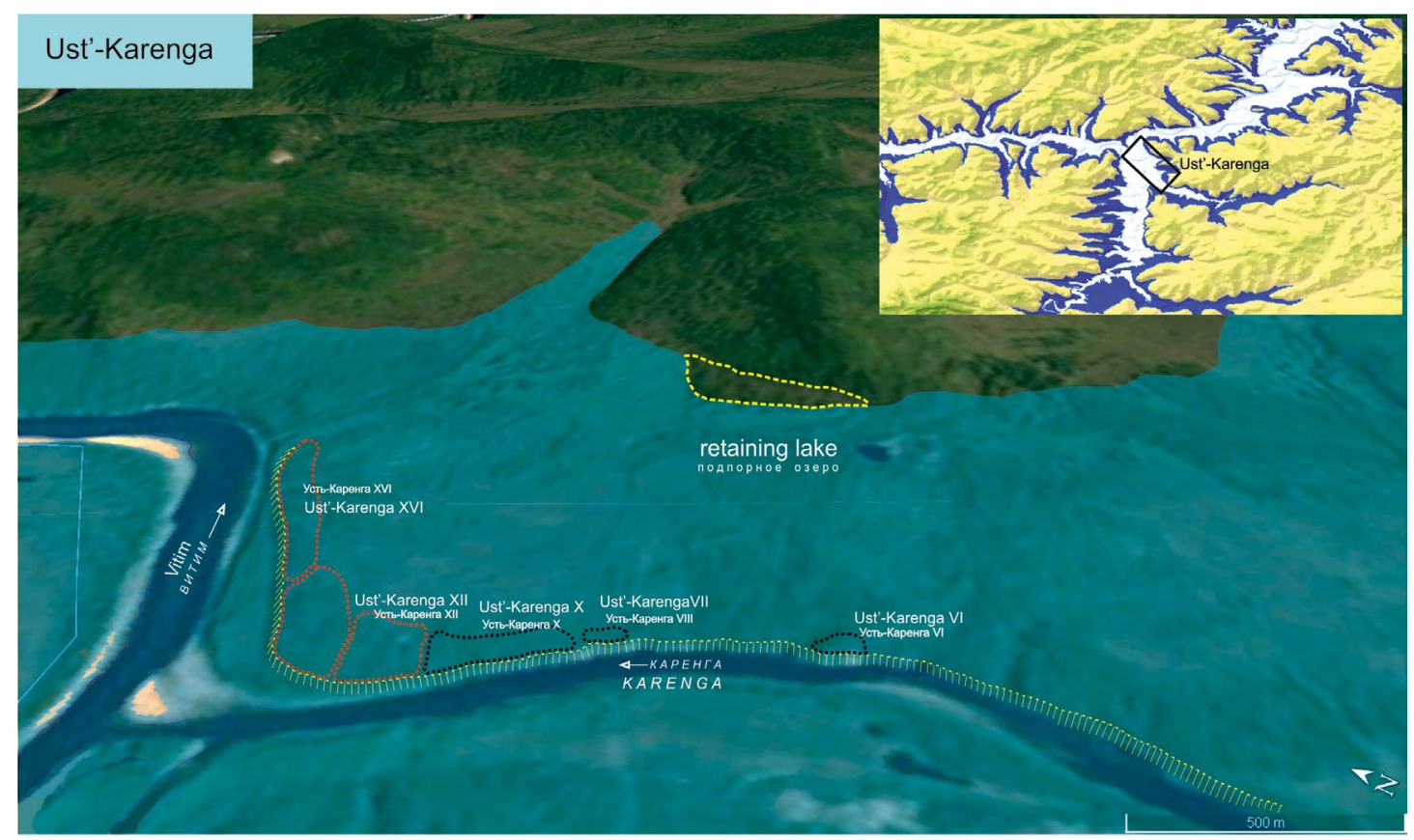

Fig.6. The level of the palaeolake of the Sukhokit stage (elevation $740 \mathrm{~m}$ above sea level) at the mouth of the Karenga River and archaeological sites buried by lacustrine sediments. 
terms, we can say that the sites of the Ust'-Karenga archaeological complex were formed about 50-370 years earlier than catastrophic flooding associated with the formation of the palaeolake, which would have covered this section of the Vitim basin with between 23 and 63 metres of water (Fig. 2; Fig. 6). Such a catastrophic geological event must have had a dramatic effect on cultural practices and adaptation mechanisms. Indirect signs of this impact upon the ancient inhabitants of the Vitim basin have been recorded and are the subject of separate article (Vetrov and Ineshin, 2019).

Another interesting fact is the overlap of the features of these conditions of alluvium accumulation, which preceded the formation of soil and the features of the conditions of alluvium accumulation at the archaeological site Bol'shoy Yakor I, which is located 550 kilometres downstream of the Vitim (Fig. 1C) (Ineshin and Tetenkin, 2010). There, in the section of the terrace at an elevation of 14 metres, river alluvium was formed under the action of the same mechanisms, with the same periodicity and at the same time as those seen in the middle part of the Sukhokit section. The main feature revealed in the 3.5-meter strata of the floodplain alluvium of the Bolshoi Yakor is the fact that the sediments that buried the cultural remains of temporary seasonal hunting camps in the chronological range from 14,000 to 12,000 bp were deposited under conditions of a reduced flow of the Vitim River (Fig. 1).

\section{Conclusions}

Thus, as a result of the data obtained during the study of the palaeolake of the Muya-Kuanda basin, it was possible to clarify the time of formation and the duration of the existence of the dammed palaeolake of the Sukhokit stage. As research develops further in this direction, it will be possible to link these geological events more closely to a dendrochronological scale and thereby to obtain absolute calendar chronology for these catastrophic geological processes. Synchronization of the dating of this event with data on the eruption of nearby volcanoes, makes it possible, with a high degree of probability, to confirm the hypothesis put forward by A.A. Kulchitsky and G.F. Ufimtsev regarding the tectonic origin of the retaining dam that blocked Vitim and its location (Kulchitsky et al., 1997). Further research will allow us to clarify this relationship with new dates on organic material associated with this volcanism. However, annual rings in the trunks of larch trees from the Sukhokit stump horizon indirectly testify in favor of a tectonic rather than the glacial origin for the retaining dam. The cold dry climate reflected in the annual rings do not indicate conditions in which we might expect the formation of significant masses of ice across the North Muya ridge. Further study of buried wood in the Muya-Kuanda basin will allow us to compile high resolution palaeoclimatic models with the possibility to explore real cause-and-effect models for the relationships between natural events and the activities and traditions of the ancient populations of the Vitim basin. Already, the results obtained made it possible to synchronize aspects of the settlement of the Vitim valley and the catastrophic events associated with the emergence of the Sukhokit stage palaeolake (1196710564 bp). Undoubtedly, these apparently catastrophic events played a significant role in the preservation of the remains of human activity. The burial of these sites in $1.4 \mathrm{~m}$ of sterile lacustrine alluvium enabled us to obtain clear in situ evidence for one of the oldest ceramic industries in Northern Eurasia (11870 - 12175 bp) (Fig. 2). The formation of overlapping cultural remains of sands near the conditions of a backwater lake is also confirmed by data on diatoms and pollen from the section. The climatic conditions, reflected in the graph of the growth of annual rings in wood from the stump horizon, directly reflect with a high degree of detail the living conditions of the ancient population at the sites of the Ust'-Karenga archaeological complex and Bol'shoy Yakor I downstream of the Vitim. If we consider that ceramic production must have been an important adaptive strategy for these communities living in the harsh conditions of North Asia (conditions directly attested in the tree ring data) we can assume that the survival of human communities was possible thanks to the careful management of food resources. Movements of groups of the ancient population from sites at the mouth of the river. Karenga to the areas of the lower reaches of the Vitim is attested by observations and analyzes on the movement of exotic rocks of stone raw materials, which allows us to consider the oldest layers of the Ust'-Karenga complex as the remains of the base sites of ancient hunter-fisher-gatherers, who developed a unique model of economic activity for the development of mountain landscapes of the Vitim plateau (Ineshin and Tetenkin, 2010).

\section{Acknowledgements}

The dating work for the project was supported by SUERC and the Prehistoric Society

\section{Conflict of interests}

Authors declare no conflict of interests.

\section{References}

Cook E.R., Anchukaitis K.J., Buckley B.M. et al. 2010. Asian monsoon failure and megadrought during the last millenium. Science 328(5977): 486-489. DOI: 10.1126/ science. 1185188

Endrikhinsky A.S., Osadchiy S.S., Agafonov B.P. et al. 1983. Geologiya i seysmichnost' zony BAM. Kaynozoyskiye otlozheniya i geomorfologiya [Geology and seismicity of the BAM zone. Cenozoic deposits and geomorphology]. Novosibirsk: Nauka. (in Russian)

Enikeev F.I. 2009. Pleistocene glaciations of Eastern Transbaikalia and Southeast of Central Siberia. Geomorfologiya [Geomorphology] 2: 33-49. (in Russian)

Filippov A.G. 1997. Detailing of local litho- and biostratigraphic dissection of Quaternary sediments based on the study of reference sections to improve the stratigraphic schemes of the Mui series and the Angara-Lena block of the Angarsk series in the south of Eastern Siberia. Report on research work for 1995-1997. Irkutsk. (in Russian) 
Guskova E.G., Raspopov O.M., Dergachev V.A. et al. 2012. The Gothenburg geomagnetic excursion as a benchmark of the time frame for the development of the Allerod climatic phase on the Central Russian Upland. Geofizicheskiye Processy i Biosfera [Geophysical Processes and Biosphere] 11(2): 5-15. (in Russian)

Ineshin E.M. 2003. Dynamics of the development of glacial environments and human settlement of the BaikalPatom Upland in the Pleistocene - Early Holocene (new data on the glaciology of the Baikal Upland). Izvestiya Laboratorii Drevnikh Tekhnologiy [Bulletin of the Laboratory of Ancient Technologies] 1: 50-57. (in Russian)

Ineshin E.M., Tetenkin A.V. 2010. Chelovek i prirodnaya sreda severa Baykal'skoy Sibiri v pozdnem pleystotsene. Mestonakhozhdeniye Bol'shoy Yakor' I [Man and the natural environment of the north of Baikal Siberia in the late Pleistocene. Location of big Anchor I.] Novosibirsk: Nauka. (in Russian)

Krivonogov S.K. 2001. Stump horizons in Late Pleistocene sediments of Siberia. Novosti Paleontologii i Stratigrafii: Prilozheniye k Zhurnalu "Geologiya i Geofizika" [News of Palaeontology and Stratigraphy: Appendix to the "Geology and Geophysics" Journal] 42(4): 143-152. (in Russian)

Kulchitsky A.A., Orlova L.A. 1991. The absolute age of the stump horizon of the terrace-like surface of the Muya valley. In: Geomorphological Seminar "Vremya i Vozrast Rel'yefa [Time and Age of the Relief]", pp. 146-147. (in Russian)

Kulchitsky A.A., Skovitina T.M., Ufimtsev G.F. 1997. Dam lakes in the bottom of the rifts of Eastern Siberia: evidence from the past and the likelihood in the future. Geografiya i Prirodnyye Resursy [Geography and natural resources] 1: 61-65. (in Russian)

Margold M., Jansen J.D., Codilean A.T. et al. 2018. Repeated megafloods from glacial Lake Vitim, Siberia, to the Arctic Ocean over the past 60,000 years. Quaternary Science Reviews 187: 41-61. DOI: 10.1016/j.quascirev.2018.03.005

Mörner N.-A. 1977. The Gothenburg magnetic excursion. Quaternary Research 7(3): 413-427. DOI: 10.1016/0033-5894(77)90031-X

Nowaczyk N.R., Arz H.W., Frank U. et al. 2012. Dynamics of the Laschamp geomagnetic excursion from Black Sea sediments. Earth and Planetary Science Letters 351-352: 54-69. DOI: 10.1016/j.epsl.2012.06.050

Stupak F.M. 1987. Kaynozoyskiy vulkanizm khrebta Udokan [Cenozoic volcanism of the Udokan ridge]. Novosibirsk: Nauka. (in Russian)

Stupak F.M., Stupak R.M. 1987. Posledovatel'nost' vulkanicheskikh proyavleniy kaynozoya $\mathrm{v}$ khrebte Udokan [The sequence of volcanic manifestations of the Cenozoic in the Udokan ridge]. In: Conference "Geologiya kaynozoya Vostochnoy Sibiri", p. 36. (in Russian)

Vetrov V.M., Ineshin E.M. 2019. The most ancient ceramics of Baikal Siberia in the context of the traditions of ceramics of East Asia. Vestnik Sankt-Peterburgskogo Universiteta. Istoriya [Vestnik of Saint Petersburg University. History] 64(2): 453-473. (in Russian) DOI: 10.21638/11701/ spbu02.2019.205 